\title{
Література:
}

1. Анімізм. Вікіпедія. URL: https://uk.wikipedia.org/wiki/\%D0\%9 0\%D0\%BD $\% \mathrm{D} 1 \% 96 \% \mathrm{D} 0 \% \mathrm{BC} \% \mathrm{D} 1 \% 96 \% \mathrm{D} 0 \% \mathrm{~B} 7 \% \mathrm{D} 0 \% \mathrm{BC}$ звертання: 28.06.21)

2. Веселовский А. Миф и символ. Русский фольклор. Ленинград: Наука, 1979. Т. ХІХ: Вопросы теории фольклора. С. 186-199.

3. Гуменюк Б. Соняхи. Блокпост. URL: https://www.facebook.com/ 690230277770764/posts/846681388792318/ (дата звертання: 30.06.21).

4. Жадан С. Інтернат. Чернівці: Meridian Czernowitz, 2017. 336 c.

5. Зіненко Р. Іловайський щоденник. Харків: Видавництво «Фоліо». 2020. 282 с. (Серія «Воєнні щоденники»).

6. Михайлишин I. «Танець смерті. Щоденник добровольця батальйону «Донбас». Харків: Фоліо, 2020. Серія «Воєнні щоденники». 315 с.

7. Міліана. Соняшник як символ. URL: https:// ukraine. ejournal.com/ 461123.html (дата звертання: 24.06.21).

8. Символ. Літературознавчий словник-довідник. Р.Т. Гром'як, Ю.І. Ковалів та ін. Київ: ВЦ «Академія», 1997. С. 365.

9. Цуркан I. Лірика Олександра Олеся: поетика символізму. URL: https://shron1.chtyvo.org.ua/Tsurkan_Ihor/Liryka_Oleksandra_Olesia_ poetyka_symvolizmu.pdf? (дата звертання: 24.06.21).

10. Шкляр В. Чорне сонце: збірка. Харків: Клуб сімейного дозвілля, 2015. $304 \mathrm{c}$.

DOI https://doi.org/10.30525/978-9934-26-110-7-13

\section{POPULARIZATION OF UKRAINIAN LITERATURE BY UKRAINIAN WRITERS ABROAD}

\author{
Lychuk S. V. \\ Candidate of Philological Sciences, \\ Associate Professor at the Department of Linguistics \\ Ivano-Frankivsk National Medical University \\ Ivano-Frankivsk, Ukraine
}

Distribution of Ukrainian products abroad. Undoubtedly, the publishing houses play an important role in the dissemination of translated literature. We can talk about various forms of support for the translation of Ukrainian literature in English from outside Ukraine. This is the publication of the literary almanac of the youngest generation of Ukrainian 
writers "Half a Breath" (Half a Breath: A Brief Anthology of Young Ukrainian Writers: TEKA Publishing House, 2009) with the support of the British Council in Ukraine, the Public Organization "Forum Publishers" and the International Literary Festival in Lviv; and the creation of small publishing centers - the UK publishing house "Kalyna Language Press", founded by Stiven and Sjuzi Komarnicki; and a private publishing house "Language Lanterns Publications" in Canada, which publishes anthological and individual book editions of classical and contemporary Ukrainian prose; and the creation of the "Ukrainian Literature" magazine, edited by Maxim Tarnavsky (financial support of the Taras Shevchenko Scientific Society and personally by its president prof. Larisa Zaleska Onyshkevich); and the Grant Program of the "Open Ukraine" Foundation - the "Book Fund" (International Literary Festival in Edinburgh, Scotland) of the Ukrainian poet and publisher Mariana Savka (2008), the English edition of Almanac of the Contemporary Ukrainian Literature (Contemporary Ukrainian Literature: Review, 2009) etc.

London publishing houses "Vintage" and "Harvill Secker" (15 editions by 2013) publishe high-quality products of modern literature and a small joint British-Dutch publishing house "Glagoslav Publications", which publishes translations of artistic and non-artistic prose of the Slavic (Ukrainian, Russian, Belorussian) Literature (7 Ukrainian publications).

Stiven Komarnicki is a co-founder (with Sjuzi Komarnitska) of its own online publishing house "Kalyna Language Press" in the UK, distributing Ukrainian literature among its readership. His active position is also found in the literary readings of Ukrainian literature in English (directly involved), prepared by the British edition "Modern Poetry in Translation" (editors David and Helen Constantin) in London in 2007 [2, p. 173].

The Ukrainian literature is presented in two forms in the European market. In our opinion, the printed form presents less works than electronic ones. During this period, the magazine "International Poetry" published translations of 13 important Ukrainian poets of contemporary Ukrainian literature: Yuriy Andrukhovych, Natalka Bilotserkivets, Andriy Bondar, Oleg Lishega, Sergei Zhadan, Oksana Zabuzhko, Vasyl Makhno, Mykola Ryabchuk, Galina Kruk, Victor Neborak and others.

We will mention the magazine of European culture "Eurozine" from electronic journals, which, in particular, publishes an article by Timothy Gavrilov "Literary Prospects: Ukraine. Sad for the novel" [1]. Michael Naydan's article "The New Ukrainian Women's Prose: twenty years after Independence" was published in magazine "World Literature Today" [3]. 


\section{Popularization of Ukrainian literature by Ukrainian writers.}

No less important factor in the presentation of the Ukrainian word is the direct participation of the artists themselves in various cultural events, festivals and open reading.

Ukrainian writers representing Ukraine at international festivals, forums, readings, promote the native language in the Netherlands (annual Rotterdam International Poetry Festival): Yuriy Andrukhovych, Natalka Bilotserkivets, Andriy Bondar, Sergiy Zhadan, Oksana Zabuzhko, Galina Kruk; Scotland (International Literary Festival in Edinburgh): Igor Pavlyuk, Maryana Savka, Andriy Kurkov; presentation of the Ukrainian magazine of foreign literature "Universe" (Cambridge University) etc.

The publication of almanac of the contemporary Ukrainian literature (Contemporary Ukrainian Literature: Review, 2009) and the literary almanac of the selected works of the younger generation of Ukrainian writers (Half a Breath: A Brief Anthology of Young Ukrainian Writers: TEKA Publishing House, 2009) loudly declared about Ukraine in the world.

Ukrainian poetry has released 3 issues of the periodical magazine "Ukrainian Literature" (Ukrainian Literature. A Journal of Translations, 2004, 2007, 2011) edited by Maxim Tarnavsky and thematic issue "International Poetry Review" (IPR Issue XXXVII 2, Fall 2010) in edition Michael Naydan.

The private publishing house "Language Lanterns Publications" (Toronto, Canada), founded by Roma Franco and Soni Morris, distributes anthologies of classical and contemporary Ukrainian small prose, and the publishing house of the scientific literature of humanitarian and social direction "Toronto University Press" has published 6 editions.

The author's meetings of Ukrainian writers with American readers are carried out thanks to the translation project of Mark Andreichik "Contemporary Ukrainian Literature" (Contemporary Ukrainian Literature. Series), implemented with the support of the Ukrainian studies studios at the Harriman Institute of Columbia University and the Kennan Institute (USA).

\section{References:}

1. Eurozine: $\quad$ http://www.eurozine.com/articles/2007-06-28-havryliven.html

2. Komarnytskyi, S. 2012. Intehratsia Ykrainy $v$ Yevropu maye rozpochatysya na rivni dialohu kultur [Integration of Ukraine into Europe should begin at the level of the dialogue of cultures]. Vsesvit (5-6). 169-173.

3. World Literature Today. 2011. http://www.worldliteraturetoday.org/2011/november/emerging-ukrainianwomen-prose-writers-twenty-yearsafter-independence\#.URMDe6W6d8t 